\title{
Gastropods of the Lower Jurassic Hierlatz Limestone Formation, part 4. New eucycloidean, trochoidean, neritimorph, and caenogastropod taxa in the fauna of the Hierlatz Alpe (Hallstatt, Austria)
}

\author{
János SzABó \\ Department of Palaeontology and Geology, Hungarian Natural History Museum, \\ H-1083 Budapest, Ludovika tér 2, Hungary.E-mail:szabo.janos@nhmus.hu
}

\begin{abstract}
Twelve gastropod species, new for the locality, are added to the Lower Jurassic fauna of the Hierlatz Alpe. Most of them represent also new taxa, four genera and seven species: Biconomphalus singularis n. gen. n. sp., Karsaconulus robustus n. gen. n. sp., Csigabaga nillae n. gen. n. sp., Hierlatzella arcana n. gen. n. sp., Eucyclomphalus? subgradatus n. sp., Cupaniella praebiplicata n. sp., and Callotrochus? avernoides n. sp. With 71 figures.
\end{abstract}

Key words - Biconomphalus, Csigabaga, Early Jurassic, Gastropoda, Hierlatzella, Hierlatz Limestone, Karsaconulus

\section{INTRODUCTION}

This paper continues publishing gastropod species that are still new for the fauna of the type locality area of the Lower Jurassic Hierlatz Limestone Formation (Hierlatz Alpe, Hallstatt). Some of them represent also newly recognised taxa of Gastropoda. Mostly, they belong to the accessorial components and document unique evolutionary results.

\section{LOCALITY, MATERIAL, AND METHODS}

The majority of specimens, studied in this paper, are from the oldest, 19th century collections of the Geologische Bundesanstalt (GBA, Vienna, Austria); they remained still unidentified or misidentified up to now. Other specimens have been selected and correctly labelled but have not been published by an anonymous palaeontologist as "new species"; these specimens may be also from the old collections. One of the new species was found in a small Hierlatz Alpe Lower Jurassic collection of the Hungarian Natural History Museum (HNHM, Budapest, Hungary). Originally they belonged to the collections of a fossil hunter, Rezső Streda, who was active in the first half of the 20th century in Hungary. 
More information about the locality and the material is supplied in former papers on the Hierlatz Alpe gastropod fauna (SzABó 2009, 2017, 2018).

\title{
SYSTEMATIC PALAEONTOLOGY
}

\author{
Class Gastropoda Cuvier, 1795 \\ Subclass Vetigastropoda Salvini-Plawen, 1980 \\ Superfamily Eucycloidea Koken, 1897
}

\begin{abstract}
Remarks - Recently two main opinions have evolved to classify this highly diversified, major Mesozoic gastropod group. One regards it as an early derived family of Seguenzioidea (FERRARI et al. 2014), and this view has been adopted also in the new classification of Class Gastropoda by Bouchet et al. (2017). The other opinion considers the origin of the Eucycloidea independent from the Seguenzioidea (BANDEL 2009, 2010). Here, the latter suggestion is followed; for a more detailed discussion of this question, see SzABó et al. (in press). Three eucycloidean families are identified in the available material; however, presence of Eucyclidae is uncertain. The family interpretation follows mainly the suggestion by GRÜNDEL (2007) that has originally introduced this subdivision on the subfamily level.
\end{abstract}

Family ?Eucyclidae Koken, 1897

Biconomphalus n. gen.

Type species - Biconomphalus singularis $\mathrm{n}$. sp.

Derivation of name - Name refers to the biconoidal shell shape and the associated umbilicus.

Diagnosis - Biconoidal, thin walled shell with low whorls of quadrangular cross-section. Whorl surface convex but almost flat, suture following former periphery in shallow depression. Periphery simply angular on early shell but becoming keel-like on last whorl. Base wall feebly convex then changing into somewhat concave on latest half whorl. Moderately broad umbilicus, having sharply angular rim. Peristome discontinuous at parietal region. Ornament of sparse, prosoclineprosocyrt riblets on initial teleoconch, dense, prosocline-straight threads subsequently; all collabral. Basal growth lines opisthocyrt. Obscure spiral lines on whorls; various, dense spiral threads on base.

Remarks - The shell of Biconomphalus n. gen. resembles that of Eucyclomphalus von Ammon, 1892. The two genera most prominently differ in the form of the base; while this shell part is almost flat walled in Biconomphalus n. gen., so the 
entire base well approaches the shape of a cone, Eucyclomphalus has subglobular base with strongly convex wall. Another difference is in the formation of the suture that is almost flush on the whole shell of Biconomphalus n. gen. but impressed below the periphery in Eucyclomphalus so causing a subpagodiform outline. The late teleoconch of Sertomphalus Gründel, 2007 shows the same differences as Eucyclomphalus from Biconomphalus n. gen. They differ also in the earliest growth phases; the early teleoconch of Sertomphalus is markedly coeloconoidal, Biconomphalus n. gen. has simple cone outline. This shell part is poorly known in the type species of Eucyclomphalus.

The short diagnosis from GRÜNDEL (2007) permits to place Biconomphalus n. gen. into Eucyclidae; however, it is an extreme form amongst the other genera, which have more or less pagodiform shell and rather subglobose base with more convex wall. That is why the attribution of Biconomphalus n. gen. to Eucyclidae must be regarded as uncertain.

Biconomphalus singularis $\mathrm{n}$. sp.

(Figs 5-9)

Type specimen - Holotype: GBA 2019/009/0001.

Type locality - Hierlatz Alpe (Hallstatt, Austria).

Type strata - Lower Jurassic Hierlatz Limestone from the Semicostatum Zone (Lower Sinemurian) to Jamesoni Zone (Lower Pliensbachian) interval.

Derivation of name - Singularis $($ Latin $)=$ single, referring to the only known specimen and species in the genus.

Diagnosis - Same as for the genus.

Material - The holotype only.

Measurements - Holotype, $\mathrm{D}=8.1 \mathrm{~mm}$.

Description - The available shell has a moderately high, conoidal spire with blunt apex and a lower basal conoid. All whorls, having almost flat but convex surface, are edged by feebly impressed, almost flush suture. The periphery is sharply angular. Wall of the base is convex a little on the earlier whorls then changing into feebly concave in the latest growth phase that means about the last half coil. Deepest part of this concavity is observable along the periphery and this narrow belt is concave also on the earlier base parts. The umbilicus is moderately broad with a sharply angular rim. In cross-section, the whorls are quadrangular; the aperture and the peristome must be similarly shaped but no parts of theirs are preserved; in lack of any parietal encrustation, the peristome appears to be discontinuous there.

The earliest teleoconch whorl bears the sparse, suture to suture eucycloidean riblets that are substituted on the subsequent whorls by denser and thinner 
collabral threads, extending usually from suture to suture but some shorter ones, which do not reach the upper suture, also occur. These threads are crossed by very thin or obscure spiral lines on the whorls. Stronger, dense spiral lines give the main ornament of the base but a few marked threads also occur along the periphery and around the umbilicus. The growth lines are prosocline on the whorls and opisthocyrt on the base.

Remarks - The shape of Biconomphalus singularis $\mathrm{n}$. sp. is similar to that of the type species of Callotrochus Kutassy in Wenz, 1938 but this latter one does not have any trace of eucycloidean (early) ornament. Eucyclomphalus hierlatzensis specimens in early growth stages may show similar appearance because of their ornament, composed of also fine collabral threads on the whorls. However, the differences mentioned in the genus distinction are recognisable also on these shell parts although in less marked form.

Occurrence - Within Sinemurian to lowermost Pliensbachian (Lower Jurassic) part of the Hierlatz Limestone Formation in Hierlatz Alpe, Hallstatt, Austria.

Family Eucycloscalidae Gründel, 2007

Genus Riselloidea Cossmann, 1909

Type species - Risellopsis subdisjuncta Cossmann, 1908

Remarks - Ferrari et al. (2014) and FerRARI \& Kaim (2018) discussed the relations between the fossil and recent eucycloideans and concluded that the shell morphology of Calliotropis and Riselloidea does not differ significantly because "the absence/presence of umbilicus seems to be an unstable character". This is true for the cases when anomphalous and umbilicate species equally occur with similar shells more or less contemporaneously, e.g. in most pleurotomariid genera. If the two species groups are so clearly separated temporarily like in the case of Riselloidea (Mesozoic) and Calliotropis (Cenozoic to Recent), both the lack and presence of an umbilicus must be accepted as genus characters. Additional data, like shape and size differences in the protoconchs of the two groups (FERRARI $e t$ al. 2014, p. 1181), emphasize the distinction of these genera.

FERRARI \& KAIM (2018) mention two umbilicate Jurassic species which might support the unification of the two genera. From these species, Riselloidea multistriata (Böckh, 1874) has only a pseudoumbilicus; actually it is anomphalous, while the periaxial basal region in Calliotropis erraticus Gründel \& Kopka, 2007 (Pl. 1, Fig. 3) remained filled by sediment in its monotype. Inference of an umbilicus, reflected in the diagnosis of this species needs yet verification. The early teleoconch morphology of Riselloidea indicates its family position in Eucycloscalidae Gründel, 2007. 
Riselloidea noszkyi Szabó, 1995

(Figs 10-14)

1995 Riselloidea noszkyi sp. n. - Sza Bó, p. 71, pl. 7, figs 1-3.

2009 Riselloidea noszkyi Szabó - SzABó, p. 83, Fig. 78.

Material - Two fragmentary shells (GBA 2019/009/0002-3).

Measurements - (GBA 2019/009/0002), D $=10.5 \mathrm{~mm}$, whorl fragment (GBA 2019/009/0003), $\mathrm{H}=7.2 \mathrm{~mm}$.

Description - The available specimens have turbiniform-subgradate shell with convex whorls and flat, anomphalous base of feebly convex wall; the transition of the last whorl to the base is rounded angular. Surface of the whorls is composed of a few feebly concave belts between pairs of carinae or the peripheral carina and the suture, respectively. The number of these belts and carinae somewhat increases during the growth; the new carinae are added along the adapical suture. For the last whorl, five carinae develop; the lowermost one is overlapped by the suture on the spire whorls. The most prominent carina, providing also the periphery, runs adapically next to the suture. So the suture itself has an impressed position. Several sparsely but regularly distributed spiral cords are also on the base, they are similar in strength to the carinae of the whorl surface.

On the whorl surface, the carinae are sparsely spiny, riblets start from these spines collabrally towards the neighbouring carinae. The spines become strong, adaperturally open processes on the strongest carinae and follow each other scaly way. On the early whorls, the riblets frequently vanish within the interspace of the carinae but on the latest two whorls, they form a network ornament. Very thin, subregularly repeated growth threads occur between the riblets. Spines are lacking from the spiral cords of the base and they are gradually thinner and denser in adaxial direction. Dense, feebly opisthocyrt growth lines or growth threads between the peripheral and the axial parts cross them. On the whorl surface, the growth lines are prosocline, slightly on the early whorls but strongly on the last whorl with gradual change.

Remarks - This species has been established on poorly preserved specimens from the Bakony Mts (Sümeg, Hungary). Now some new characters can be added to the morphology from the Hierlatz finds; they have helped to recognise the scaly nature of the nodules on the peripheral and its adapically neighbouring keels. These nodules suggest crenulate undamaged form of the otherwise not preserved outer lip. The two Hierlatz Alpe specimens indicate that the density of the scaly nodules and the connected collabral threads are probably very much variable.

Occurrence - Within Sinemurian to lowermost Pliensbachian (Lower Jurassic) part of the Hierlatz Limestone Formation in Hierlatz Alpe, Hallstatt, Austria and Sümeg (Bakony Mts, Hungary) Upper? Sinemurian Hierlatz Limestone. 
Genus ?Eucyclomphalus von Ammon, 1892

Type species - Trochus cupido d'Orbigny, 1850

Remarks - Seemingly, the teleoconch morphology of Eucyclomphalus well matches to the diagnosis of Eucyclidae, but the earliest shell parts of the type species are still unknown. The next species has many characters in common with Eucyclomphalus but the small remnant of the earliest teleoconch whorl of the available specimen bears two peripheral spiral threads, which indicate eucycloscalid relation by GRÜNDEL (2007) system.

Another generic position of the next species could be in Lokuticyclus Szabó, 1995, having also phaneromphalous shell but without any peripheral angulation in all available specimens. This genus has been established as subgenus in Eucyclus J.-A. Eudes-Deslongchamps, 1860 but, with the new interpretations of Eucyclidae (GRÜNDEL 2007) and the nominate genus (FERRARI et al. 2014), Lokuticyclus must be regarded as an independent genus in an uncertain eucycloidean family accommodation since the earliest teleoconch whorls have yet been unknown in all species.

As a conclusion: the family position of the next species appears resolved but the generic attribution remains dubious. It is simply a new species if Eucyclomphalus was member of Eucycloscalidae but represents also a new genus in this family if it was component of Eucyclidae.

\section{Eucyclomphalus? subgradatus n. sp.}

(Figs 1-4)

Type specimen - Holotype: GBA 2019/009/0004.

Type locality - Hierlatz Alpe (Hallstatt, Austria).

Type strata - Lower Jurassic Hierlatz Limestone from the Semicostatum Zone (Lower Sinemurian) to Jamesoni Zone (Lower Pliensbachian) interval.

Derivation of name - The name is formed as reminder to one of the specific characters of this new species, the weakly developed gradate outline of the spire.

Diagnosis - High conoidal shell with low whorls. Earliest and latest teleoconch whorls evenly convex; intermediate whorls having weak angulation at midwhorl and at periphery; latter one bearing strong, single cord. Second preserved whorl having dense, collabral threads and four spiral threads. Lowermost spiral one overlapped by suture; adapical neighbour becoming peripheral cord, other two becoming ribbons afterwards. Collabral threads lacking from latest whorls. Base bearing dense spiral ornament, mostly thin threads and few cords.

Material - Single specimen with damages and matrix pieces on the shell, risky to remove.

Measurements - Holotype (GBA 2019/009/0004), D = $10.4 \mathrm{~mm}$. 
Description - The species is represented by a moderately high conoidal shell that consists of about nine low, convex whorls, which are more than three times wider than the maximum distance of the limiting sutures in the latest growth phases. Already on the earliest observable whorl, a weak angulation is visible slightly above the suture; it persists also on all following whorls though it becomes rounded for the latest growth stages. This angulation provides the periphery for all whorls. The suture is deeply impressed below the peripheral angulation and the outermost belt of the base remains exposed also on the spire. Another but obscure angulation also develops somewhat below the midwhorl for the latest 3-4 whorls. Initially, the subsutural ramp is fully convex then its abapical, wider belt becomes slightly concave; the outer face between the two angulations is feebly convex on all whorls. The base below the rounded part of the peripheral angulation is subglobularly convex as a whole, and it has convex wall and a broad umbilicus. No peristome part is preserved.

The earliest small whorl fragment has two spiral threads in peripheral position; no more ornament remained observable around. The next four whorls have dense, sharp, suture to suture threads that are crossed by four, similarly strong spiral threads initially, so about the abapical half of two earlier whorls shows a network ornament. On the third available early whorl, the obscure angulation of the whorl surface develops in line with the most adapical spiral thread. At the same time, the thread itself and its abapical neighbour become flat elevation but the thread, third from the apex, strengthens as a cord on the peripheral angulation. The fourth line is overlapped by the suture initially then exposed on a narrow but widening belt of the base between the periphery and the suture. In the latest growth stages, few additional, thin threads are also visible in this belt. For the penultimate whorl, the collabral threads change into irregularly spaced, flat ridges, and the uppermost two spiral treads transformed into slightly convex, wide ribbons. The shell remnants of the base in the peripheral region and at the rim of the umbilicus are covered with thin spiral threads. However, the elevations on the inner mould of the base indicate also presence of few sparsely distributed spiral cords; their subregular undulation may be caused by nodes.

The growth lines seem slightly prosocline and opisthocyrt between the sutures, actually they consist of a prosocline and gently prosocyrt part on the ramp then turn into a just feebly prosocline part on the narrow outer face then into feebly opisthocline on the peripheral part of the base.

Remarks - The shape of the early shell parts is similar to that of Eucyclomphalus bierlatzensis von Ammon, 1892 but the opisthocyrt form of the collabral threads, and the formation of an angulation on the whorl surface between the upper suture and the periphery in Eucyclomphalus? subgradatus $\mathrm{n}$. sp. distinguish the early teleoconchs of these species. On the latest whorls, the periphery becomes round- 
ed in both species; however, the size of the full-grown $E$. hierlatzensis specimens much exceeds the size of the full-grown E.? subgradatus n. sp. Moreover, spiral ribbons on the latest whorls develop only in E.? subgradatus n. sp.

Occurrence - Within Sinemurian to lowermost Pliensbachian (Lower Jurassic) part of the Hierlatz Limestone Formation in Hierlatz Alpe, Hallstatt, Austria.

Family Chilodontidae Wenz, 1938

Genus Cupaniella M. Gemmellaro, 1911

Type species - Cupaniella biplicata M. Gemmellaro, 1911

Remarks - Gemmellaro (1911) thought his new genus, Cupaniella as belonging to Cerithiidae. However, its morphology shows doubtless relationships to genera of Chilodontidae, especially to Wilsoniconcha Wenz, 1938 (nom. nov. pro Wilsonia Hudleston, 1896); possibly, they are synonymous. For the first glance, the type species of the two genera do not differ on higher than the species level. Both seem to have a pair of columellar denticles in similar position; however, they are the terminal parts of two columellar folds in Cupaniella; but the interior in the type species of Wilsoniconcha is unknown. The probability of synonymy increased as GRÜNDEL (2007) published his new species, Wilsoniconcha? tora, from the Liassic (Carixian = Early Pliensbachian) of Normandy; this species has also two columellar folds, i.e. it belongs to Cupaniella.

\section{Cupaniella praebiplicata n. sp.}

(Figs 15-19)

Type specimens - Holotype: (GBA 2019/009/0005); paratypes: (GBA 2019/ 009/0006-9).

Type locality - Hierlatz Alpe (Hallstatt, Austria).

Figs 1-19. Species of Eucycloidea. - Figs 1-4. Eucyclompalus? subgradatus n. sp., holotype (GBA 2019/009/0004). - 1-3. Apertural, basal and lateral views, $\times 2$. -4 . Details of the ornament, $\times 8$. - Figs 5-9. Biconomphalus singularis n. gen. n. sp., holotype (GBA 2019/009/0001). - 5-7. Apertural, basal, and lateral views, $\times 3$. $-8-9$. Details of the ornament on spire and base, $\times 6$. - Figs 10-14. Riselloidea noszkyi Szabó, 1995 (GBA 2019/009/0002). - 10-12. Apertural, basal, and dorsal views, $\times 2.5$. -13 . Details of the ornament, $\times 5$. -14 . Fragment of another shell with denser collabral ornament (GBA 2019/009/0003), ×2.5. - Figs 15-19. Cupaniella praebiplicata n. sp. 15. Holotype (GBA 2019/009/0005), $s=$ suture, $f=$ outer groove of the inner fold, $\times 8 .-16-17$. Young specimens, paratypes (GBA 2019/009/0006-7), arrow indicates furrow, the early phase of formation of inner (palatal) plica of last whorl, $\times 6$. - 18. Paratype (GBA 2019/009/0008), an inner mould with traces of the inner fold within penultimate and last whorl, and reflection of latest peristome, $\times 6$. -19 . A fragmentary and partly embedded, full grown specimen, paratype (GBA 2019/009/0009), letters mean the same as for Figure 15, ×6 


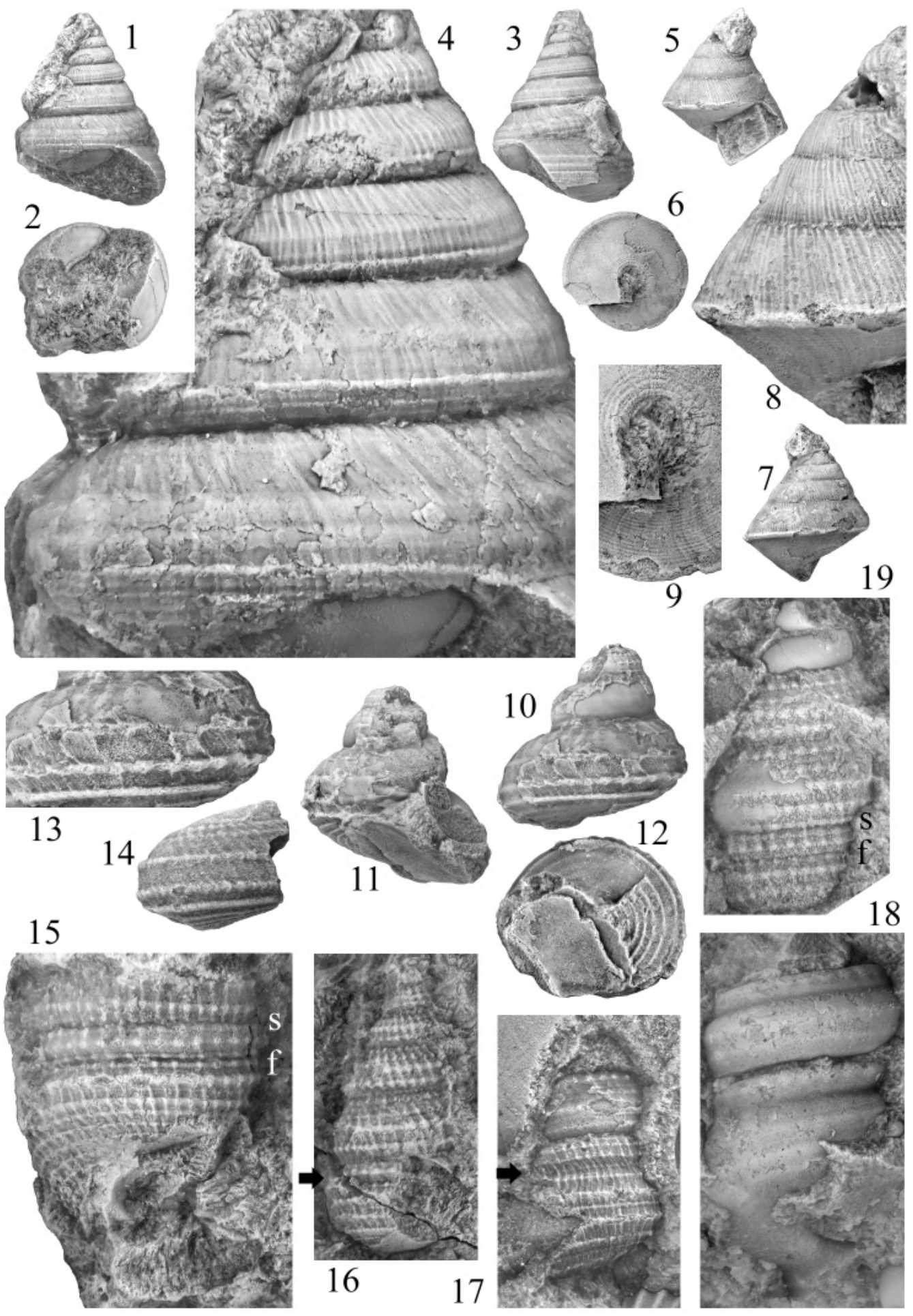


Type strata - Lower Jurassic Hierlatz Limestone from the Semicostatum Zone (Lower Sinemurian) to Jamesoni Zone (Lower Pliensbachian) interval.

Derivation of name - Referring to probable ancestral relation to the Late Pliensbachian Cupaniella biplicata M. Gemmellaro, 1911.

Diagnosis - Rather highly turriculate shell with acute early part. Subcylindrical shell part consisting of about last and penultimate whorls. Base subconoidal with feebly convex wall. Peristome clearly extending left from coiling axis. Columellar lip sharp and having two tooth-like processes on adaperturaladapical part. Parietal lip built as thin, smooth shell enamel. Near outer lip shell part outward reflecting and forming wide arch. From penultimate whorl shallow, subsutural depression appearing then becoming deeper and narrower and forming false fold internally. Network ornament of spiral threads and cords, crossed by collabral threads on whorls and base.

Material - Six fragmentary specimens (GBA 2019/009/0005-10) mostly embedded in strongly recrystallised, hard matrix. They represent almost all ontogenetic stages so the shell form can be quite well reconstructed.

Measurements - Holotype (GBA 2019/009/0005), W = $4.5 \mathrm{~mm}$, paratype (GBA 2019/009/0006), $\mathrm{H}=7.2 \mathrm{~mm}$, paratype (GBA 2019/009/0007), $\mathrm{H}=$ $4.8 \mathrm{~mm}$, paratype (GBA 2019/009/0008), $\mathrm{W}=4.7 \mathrm{~mm}$, paratype (GBA 2019/ 009/0009), $\mathrm{H}=7.3 \mathrm{~mm}$.

Description - The reconstructed shell is rather highly turriculate and pupiform. Its early parts, consisting of about seven whorls, are acute but the penultimate and latest whorls change into sub-cylindrically coiled with a base that is subconoidal. The early whorls are convex and bear a sharp spiral angulation just above the impressed suture. For the latest two whorls, the suture becomes similar to an incision and the angulation above it apparently vanishes. Almost simultaneously, a narrow and shallow spiral concavity appears in subsutural position that rapidly deepens and its edges gradually approach each other. For the last whorl, the two rims are closed, and the former furrow looks like the suture. This concavity forms a false spiral fold within the shell that is reflected on the inner mould as a furrow. The last half whorl tends downward and to adaxial direction in such degree that the peristome and the aperture get partly left from the coiling axis. The columellar lip has a sharp edge with two tooth-like processes on its adapertural-adapical part. The parietal lip is built as a thin, smooth shell enamel. The outer lip forms a wide arch between the suture and the foot of the columella and it is outward reflected.

The teleoconch has network ornament of spiral threads and cords, crossed by thin collabral threads equally on the whorls and the base. Granules or short spines are sitting at the intersections. 
Remarks - Cupaniella biplicata M. Gemmellaro, 1911 differs from Cupaniella praebiplicata n. sp. in the lack of the marked inner fold - outer furrow complex. The shell outline is also different: the last three whorls have cyrtoconoidal, almost cylindrical outline in C. biplicata but more slender in C. praebiplicata n. sp. with feebly coeloconoidal earliest parts. The earliest shell parts are cyrtoconoidal in C. biplicata.

In more precisely dated localities, C. biplicata occurred in Late Pliensbachian strata while the Hierlatz Alpe specimens are most probably Sinemurian, or Early Pliensbachian; they seem to belong to the same evolutionary lineage.

Occurrence - Within Sinemurian to lowermost Pliensbachian (Lower Jurassic) part of the Hierlatz Limestone Formation in Hierlatz Alpe, Hallstatt, Austria.

Superfamily Trochoidea Rafinesque, 1815

Family ?Calliostomatidae Thiele, 1924

Subfamily Callotrochinae Szabó, 2011

Genus ?Callotrochus Kutassy in Wenz, 1938

Type species - Trochus (Mesotrochus) triadicus Kutassy, 1927

Callotrochus? avernoides n. sp.

(Figs 20-25)

Type specimens - Holotype: HNHM, M 59.157; paratype: HNHM, M 57.3617.

Type locality - Hierlatz Alpe (Hallstatt, Austria).

Type strata - Lower Jurassic Hierlatz Limestone from the Semicostatum Zone (Lower Sinemurian) to Jamesoni Zone (Lower Pliensbachian) interval.

Derivation of name - Referring to the similarity to Proconulus avernus (Stoliczka, 1861).

Diagnosis - Proconuliform thin walled shell with barely convex to flat whorls and flush suture. Subconoidal base with shallow concavity around narrow umbilicus. Whorls and base with weak, evenly spaced spiral lineation.

Material - Two fragmentary specimens from the collections of R. Streda. The specimens have been registered as "Trochus epulus d'Orb." in the collection of the HNHM.

Measurements - Holotype HNHM, M 59.157, W $=10.1 \mathrm{~mm}, \mathrm{H}=14.7 \mathrm{~mm}$; paratype, $\mathrm{W}=10.9 \mathrm{~mm}, \mathrm{H}=14.7 \mathrm{~mm}$.

Description - Shells are thin walled, biconoidal and their shape closely approaches the form of the typical Proconulus species. It means a conoidal spire with feebly convex whorls that are separated by almost flush suture. Last whorl turns through a rounded-angular periphery into a subconoidal base, having feebly convex wall that changes into slightly concave around the abapical part of the 
umbilical lip that encloses a narrow umbilicus. The whorl cross-section is quadrangular; its abapical-abaxial angle is strongly rounded; meeting of the umbilical and the basal lip is slightly rounded angular in nearly $90^{\circ}$.

Dense, rather weak spiral threads of slightly variable thickness give the ornament of the whorls; similarly wide, shallow furrows separate them. Poorly preserved remnants show that the base is probably covered by similar ornament. The growth lines are delicate, slightly prosocline and straight.

Remarks - Both specimens lack the earliest and the latest shell parts. The apparent bases and umbilical lips show slight, smooth enamel that permits to assume simple, thin actual inner lip. The poor preservation precludes a safe identification on the genus level. However, the preserved parts do not exclude that this species belongs to Callotrochus, excepting the fact that the only formerly known species in this genus does not have clear spiral ornament.

The similarity to the monotype of "Trochus avernus Stoliczka" is rather high but the presence of an umbilicus in Callotrochus? avernoides n. sp. clearly distinguishes the available specimens since Stoliczka's species is anomphalous and its preserved inner lip is of Proconulus type. Besides, $P$. avernus has a deeply impressed suture while it is flush in Callotrochus? avernoides $\mathrm{n}$. sp.

Occurrence - Within Sinemurian to lowermost Pliensbachian (Lower Jurassic) part of the Hierlatz Limestone Formation in Hierlatz Alpe, Hallstatt, Austria.

Family Proconulidae Cox, 1960

Karsaconulus n. gen.

Type species - Karsaconulus robustus n. sp.

Derivation of name - Karsa $=$ first name of the author's grandson, conulus $($ Latin $)=$ cone.

Diagnosis - Small, thick-walled shells of biconoidal outline with blunt apex. Basal conoid low and having slightly convex wall. Shells anomphalous. Full-grown shells consisting of about six whorls, being strongly convex initially but changing to almost flat subsequently. Suture deeply impressed on early shell but altering into almost flush on later whorls. Periphery rounded angular. Columellar lip robust and sitting on thick, wide, periaxial elevation, surrounded by narrow furrow. Inner lip having wide, uneven, mainly concave outer face between sutural part of outer lip and foot of columella; its basal and apertural edges sharp. Aperture orbicular. Remnants of outer lip bearing sharp outer rim; in latest growth stage, last whorl and outer lip region slightly extending abaxially. Ornament of clear spiral threads from second whorl at least for one whorl then obscure spiral lines/striae 
appearing on next whorls and base. Growth lines prosocline and feebly prosocyrt on whorls, opisthocyrt on base.

Description - See the type species.

Remarks - The appearance of the shells is similar to that of Proconulus Cossmann, 1918; however, the peristomal morphology is strongly different. It has a poorly developed parietal lip while Karsaconulus n. gen. has a rather wide parietal lip there with a concave outer face, having sharp edges that continue also along the columellar lip to its widely extended, concave foot, bearing also sharp rims. In the enlarged, concave surface of the foot of columella, Karsaconulus is reminiscent to Discotectus Favre, 1913 but the full morphology of the latter genus links it to Epulotrochidae Gründel, Keupp \& Lang, 2017.

Occurrence - Within Sinemurian to lowermost Pliensbachian (Lower Jurassic) part of the Hierlatz Limestone Formation in Hierlatz Alpe, Hallstatt, Austria.

Karsaconulus robustus $\mathrm{n}$. $\mathrm{sp}$.

(Figs 26-36)

Type specimens - Holotype: GBA 2019/009/0011, paratypes: GBA 2019/ 009/0012-16.

Type locality - Hierlatz Alpe (Hallstatt, Austria).

Type strata - Lower Jurassic Hierlatz Limestone from the Semicostatum Zone (Lower Sinemurian) to Jamesoni Zone (Lower Pliensbachian) interval.

Derivation of name - Referring to the thick wall, heavy columella, and the reinforced peristome.

Diagnosis - Same as for the genus.

Material - Twelve specimens (GBA 2019/009/0011-22), which have been stored under the name "Trochus avernus" in Stoliczka's "background" material so actually they belong to the syntypes of Proconulus avernus (Stoliczka, 1861).

Measurements - Paratype (GBA 2019/009/0015), H = $8.6 \mathrm{~mm}$, paratype (GBA 2019/009/0013), W = $5.9 \mathrm{~mm}$, (GBA 2019/009/0012), $\mathrm{W}=6.8 \mathrm{~mm}$, holotype (GBA 2019/009/0011), $\mathrm{W}=7.2 \mathrm{~mm}$, paratype (GBA 2019/009/0014), $\mathrm{W}=$ $4.3 \mathrm{~mm}$, paratype (GBA 2019/009/0016), $\mathrm{W}=4.8 \mathrm{~mm}$.

Description - All available shells are small, their height rarely exceeds ten $\mathrm{mm}$. They have biconoidal outline with a moderately high and blunt spiral, and a low basal conoid. Full-grown shells consist of about six arched whorls that are strongly convex initially but changing to almost flat subsequently. The protoconch is depressed, almost planispiral. The deeply impressed suture of the early shell progressively alters into almost flush on the following shell parts. Periphery is rounded angular; shallow concavities develop along its both sides during the latest growth phases. The base is low, anomphalous and has slightly convex wall. 
Formation of a reinforced, complex peristome means the latest growth phase of the shell. The columellar lip is robust and has a thick, wide, periaxial plate as a basis that is surrounded by narrow but marked furrow. Inner lip is thick and has a wide, uneven, mainly concave outer face between the sutural part of the outer lip and the foot of columella; both its basal and apertural edges are sharp. The foot of columella forms an extended, ovate, and slightly concave pad, obliquely crossing the axis. The aperture is orbicular. Observable elements of the outer lip bear sharp outer rim and, in the latest growth stage, the last whorl and the outer lip region slightly extend abaxially.

Ornament is observable from the second whorl as marked spiral threads along at least one whorl, or slightly more then only obscure spiral lines/striae of different width are found on the next whorls and the base. The growth lines are prosocline and feebly prosocyrt on the whorls and opisthocyrt on the base.

Remarks - On the genus characters, most similarly shaped species are easily distinguishable. In the collection, this species has been stored as "Trochus avernus"; however, the figured specimen of this species, selected as lectotype by Szabó (2009), has Proconulus type peristome. All other specimens belong to Karsaconulus n. gen. In the Hierlatz Alpe fauna, Trochus kneri Stoliczka, 1861, Proconulus? kneri in SzABó 2009, is a rather similarly shaped species but its peristome is also different though it has also a peristome reinforcement.

Occurrence - Within Sinemurian to lowermost Pliensbachian (Lower Jurassic) part of the Hierlatz Limestone Formation in Hierlatz Alpe, Hallstatt, Austria.

\section{Csigabaga n. gen. \\ Type species - Csigabaga nillae n. sp.}

Derivation of name - Csiga (Hungarian) = snail; csiga-biga $=$ snail in children's language; Csigabaga $=$ the first pronunciation from Nilla, baby granddaughter of the author. The species name is dedicated also to her.

Diagnosis - Slightly cyrtoconoidal, anomphalous shell with obliquely flattened latest base and abaxially extending last whorl near peristome. Apex blunt, protoconch depressed, almost planispiral. Whorls low, their number about eight in full grown stage. Whorl surface convex and suture impressed in earliest shell parts then gradually changing into flush. Last half whorl becoming convex again. Wall of base also convex but flattened on last half whorl. Last peristome having strongly thickened, lunuliform inner lip, with wide outer face. Marked, short columellar fold at middle of columellar lip, significantly narrowing aperture. Outer lip not found in undamaged state; apparently thin as suggesting fragments. Moderate outward extension and development of concomitant subsutural con- 
cave belt on last whorl near last peristome of full grown shell. Short fold appearing on inner surface of flattened part of latest base near columella.

Ornament of few spiral lines on one early whorl. Growth lines prosocline, straight, and delicate on whorls, sickle shaped on base before last growth phase shell modifications then changing into widely parasigmoidal.

Remarks - The spirally ornamented early teleoconch(?) whorl and the extended last whorl support the proconulid family position of Csigabaga n. gen. in spite of the low early whorls, which might suggest belonging to Epulotrochidae.

Occurrence - Within Sinemurian to lowermost Pliensbachian (Lower Jurassic) part of the Hierlatz Limestone Formation in Hierlatz Alpe, Hallstatt, Austria.

\section{Csigabaga nillae n. sp.}

(Figs 37-50)

Type specimens - Holotype: GBA 2019/009/0023, paratypes: GBA 2019/009/0024-27.

Type locality - Hierlatz Alpe (Hallstatt, Austria).

Type strata - Lower Jurassic Hierlatz Limestone from the Semicostatum Zone (Lower Sinemurian) to Jamesoni Zone (Lower Pliensbachian) interval.

Derivation of name - See together with the genus name.

Diagnosis - Same as for the genus.

Material - Eight specimens (GBA 2019/009/0023-30).

Measurements - Paratype (GBA 2019/009/0024), H =9.7 mm, holotype(GBA 2019/009/0023), $\mathrm{W}=6.5 \mathrm{~mm}, \mathrm{H}=8.8 \mathrm{~mm}$, paratype (GBA 2019/009/0025), $\mathrm{W}$ $=5.5 \mathrm{~mm}, \mathrm{H}=7.2 \mathrm{~mm}$, paratype (GBA 2019/009/0026), $\mathrm{W}=6.6 \mathrm{~mm}, \mathrm{H}=10.5$ $\mathrm{mm}$, paratype (GBA 2019/009/0027), $\mathrm{W}=7.5 \mathrm{~mm}, \mathrm{H}=9.8 \mathrm{~mm}$.

Description - Shell is slightly cyrtoconoidal with a convex, anomphalous base that is convex but obliquely flattened in the latest growth stage. The last whorl is abaxially extending along the flattened base part near the last peristome. The apex is blunt, the earliest shell part is almost planispiral. All whorls are low; their number is about eight in the full-grown stage. Surface of the whorls is convex and the suture is impressed in the earliest shell parts then gradually changes into flush. The last half whorl becomes convex again and strongly convex at the latest periphery. The latest peristome has strongly thickened parietal and columellar lips, joined into broadly lunuliform inner lip with wide outer face. Single fold is formed around the middle of the low columellar lip. It seems to be missing from the spire whorls. Latest outer lip has not been found in undamaged state; by its remnants, it seems to be thin. All full-grown specimens show traces of a moderate outward extension of the last whorl near the last peristome and development of a concomitant subsutural concave belt. 


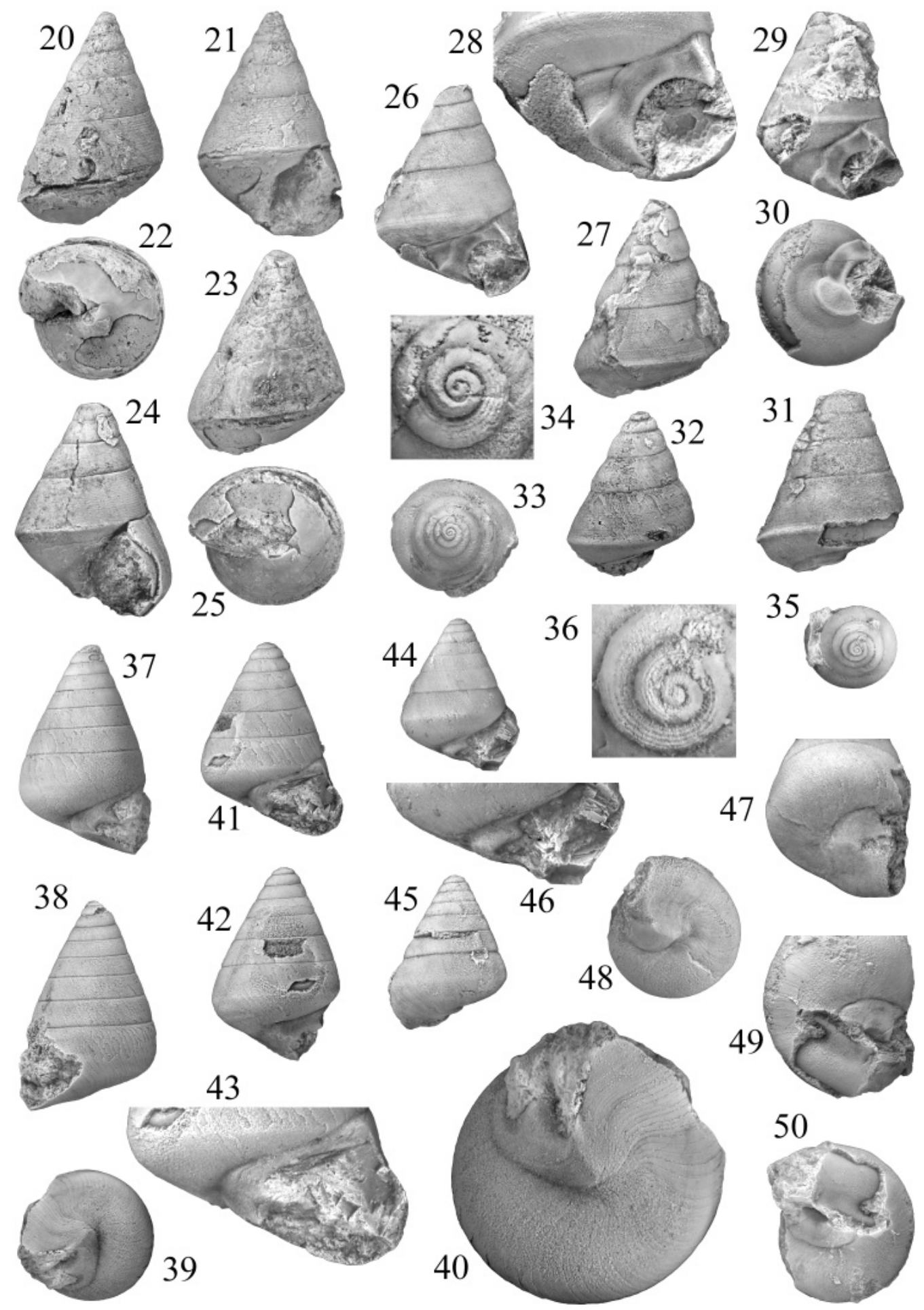


Ornament of few spiral lines is found only on one early whorl, which belongs to the protoconch or immediately follows it. The growth lines are prosocline, straight, and delicate on the whorls, sickle shaped on the base before the last growth phase shell modifications then change into parasigmoidal.

Remarks - A damaged specimen (Figs 49-50) exposes an inner basal fold that is probably present also in the other specimens. Following a marked early phase, it gradually weakens then terminates on the basal lip near the foot of columella but here it is already very low. Sometimes a shallow outer deepening seems to indicate its presence inside (Figs 47-48). Neither the columellar nor the basal fold have been found in the spire whorls of an axially cut subadult specimen. However, that specimen went through intensive, multi-phased recrystallization that could mask also the folds.

Occurrence - Within Sinemurian to lowermost Pliensbachian (Lower Jurassic) part of the Hierlatz Limestone Formation in Hierlatz Alpe, Hallstatt, Austria.

\author{
Subclass Neritimorpha Golikov \& Starobogatov, 1975 \\ Superorder Cycloneritimorpha Bandel \& Frýda, 1999 \\ Order Neritoina Rafinesque, 1815 \\ Superfamily Neritopsoidea Gray, 1847 \\ Family Neritopsidae Gray, 1847 \\ Subfamily Colubrellopsinae Bandel, 2007 \\ Genus Colubrellopsis Bandel, 2007 \\ Type species - Naticella acuticostata Klipstein, 1843
}

Figs 20-50. Species of Trochoidea. - Figs 20-25. Callotrochus? avernoides n. sp. - 20-22. Holotype (HNHM, M 59.157), apertural, dorsal, and basal views, $\times 2$. - 23-25. Paratype (HNHM, M 57.3617), apertural, dorsal, and basal views, $\times 2$. - Figs 26-36. Karsaconulus robustus $n$. gen. $\mathrm{n}$ sp. - 26-27. Holotype (GBA 2019/009/0011), apertural and dorsal views, $\times 3$. - 28. More enlarged, slightly oblique view of peristome of the holotype, $\times 5$. - 29-31. Paratype (GBA 2019/009/0012), apertural, dorsal, and basal views, $\times 3$. - 32-33. Paratype (GBA 2019/009/0013), dorsal and apical views, $\times 3$. - 34. Paratype (GBA 2019/009/0013), details of ornament of the early shell, $\times 13$. - 3536. Paratype (GBA 2019/009/0014). - 35. Apical view, $\times 3$. - 36. Detailed apical view, $\times 15$. - Figs 37-50. Csigabaga nillae n. gen. n. sp. - 37-40. Paratype (GBA 2019/009/0024). - 37-39. Apertural, dorsal, and basal views, $\times 3$. - 40. Growth line arrangements of the latest base, $\times 6 .-41-42$. Holotype (GBA 2019/009/0023), apertural and lateral views, $\times 3$. - 43. Magnification of the less damaged peristome from among the available specimens, holotype, $\times 6$. - 44-46. Paratype (GBA $2019 / 009 / 0025)$, a not fully grown specimen that shows well the columellar fold without the final peristome modifications. - 44-45. Apertural and dorsal views, $\times 3$. - 46. Aperture, $\times 6 .-47-48$. Paratype (GBA 2019/009/0026), basal views showing the place of the inner fold as shallow depression in normal and oblique position, $\times 3$. - 49-50. Paratype (GBA 2019/009/0027), a damaged shell that exposes the traces of the inner basal fold that developed during the latest growth phase, in slightly oblique and in normal views, $\times 3$ 


\section{Colubrellopsis? sp.}

(Figs 51-53)

Material - Single (GBA 2019/009/0031), badly worn specimen from a box without label but the preservation suggests its origin from the Hierlatz Limestone. Measurements - GBA 2019/009/0031, W = $13.6 \mathrm{~mm}, \mathrm{H}=15.5 \mathrm{~mm}$.

Description - The only specimen has a thick walled neritiform shell of three whorls with a depressed early shell that is homeostrophic to the teleoconch. All whorls are convex and an impressed suture separates them. Near the peristome, the last whorl slopes toward the suture in a narrow area, widening in direction of the aperture. The aperture is suborbicular; only the short columellar and the long parietal lip break the almost regular circle of the outer lip. The parietal lip appears as a thin shell encrustation that is just slightly concave on the apertural side. The basal ridge and the outer rim of the inner lip are separated by a narrow furrow; no trace of an umbilicus is visible. Outer lip is sharp and strongly prosocline; the whole apertural complex joins nearly tangentially to the last whorl.

Only collabral ornament is observable on the shell that consists of stronger and evenly spaced ribs, extending suture to the basal ridge with weaker riblets and threads of the same length in the interspaces of the formers. From about the last half whorl, the strongest elements are already lacking.

Remarks - In Neritopsoidea, BANDEL (2007) established Colubrellopsis and a very similar genus, Ladinaticella Bandel, 2007 (Tricolnaticopsidae Bandel, 2007). Actually the depressed early whorls that seem to indicate also a similarly whorled protoconch supported to choose the name Colubrellopsis? sp. for the Hierlatz Alpe find. Since its poor preservation, many details have been uncertain or unknown, therefore the generic attribution may alter; the specimen probably represents a new species.

Occurrence - Within Sinemurian to lowermost Pliensbachian (Lower Jurassic) part of the Hierlatz Limestone Formation in Hierlatz Alpe, Hallstatt, Austria.

Family ?Neridomidae Bandel, 2008

Genus ?Neridomus Morris et Lycett, 1851

Type species - Nerita haemisphaerica Morris et Lycett, 1851

Neridomus? sp.

(Figs 54-56)

Material - Single specimen (GBA 2019/009/0032) from the box, labelled as "New species".

Measurements - GBA 2019/009/0032, H = $12.2 \mathrm{~mm}, \mathrm{D}=11.8 \mathrm{~mm}$.

Description - The subglobular shell consists of three rapidly increasing teleoconch whorls and the protoconch that is damaged but seems to be rather large and 
globular. Almost all whorls are evenly convex but a narrow, shallow concave belt accompanies the otherwise almost flush suture along about a whorl length partly on the penultimate then on the last whorl. The adapertural quarter of the last whorl is downward turned, which indicates the full grown stage of the shell. Whole surface of the teleoconch lacks any ornament, only straight, prosocline growth lines are visible on the whorls with a short prosocyrt part along the adapical suture.

Remarks - Without knowledge of the peristome and the protoconch, the identification remains uncertain even on the genus level. The downward bending latest part of the shell is not characteristic in Neridomus, therefore the genus level identification seems really uncertain. Anyway, this single find indicates sporadic and/or temporary presence of neritoidean gastropods also in the Hierlatz Alpe fauna.

Occurrence - Within Sinemurian to lowermost Pliensbachian (Lower Jurassic) part of the Hierlatz Limestone Formation in Hierlatz Alpe, Hallstatt, Austria.

Subclass Caenogastropoda Cox, 1960

Superfamily Zygopleuroidea Wenz, 1938

Family Coelostylinidae Cossmann, 1909

$$
\begin{gathered}
\text { Hierlatzella n. gen. } \\
\text { Type species - Hierlatzella arcana n. sp. }
\end{gathered}
$$

Derivation of name - From the name of the type locality with -ella, diminutive suffix.

Diagnosis - Small, pupiform, thin-walled shell of low turriculate spire. Early whorls low and flat with flush suture. Last whorl downward extended and having shallow subsutural concavity. Periphery rounded angular, base convex. Peristome not fully known, disrupted or very thin at parietal region, and having simple outer lip. Axial lip composite but not fully known, seemingly tubular and corresponding to terminal part of rather thick columella, bearing narrow, conispiral umbilicus inside.

Remarks - In the lack of the earliest shell parts, the family attribution remains somewhat uncertain. However, similar simple shelled, slightly pupiform, poorly ornamented, umbilicate, Mesozoic gastropod genera are collected within Coelostylinidae. Because of the few shell characters, some genera of this family are hardly distinguishable (see e.g. case of Coelostylina and Omphaloptycha in NÜtZel \& ERWIN 2004). From these, Spirochrysalis Kittl, 1894 and some Coelostylina Kittl, 1894 species are most similar to Hierlatzella n. gen. but both differ in the lack of the heavy columella, containing the narrow, spiral umbilicus. Spirochrysalis differs also in its peculiar ornament, the spiral threads on the internal basal wall of the whorls. Hierlatzella seems to have also a short inner fold within the last whorl on its abaxial/palatal wall. It is unknown whether the umbilicus is open at the last peristome or closed like in Spirochrysalis. 

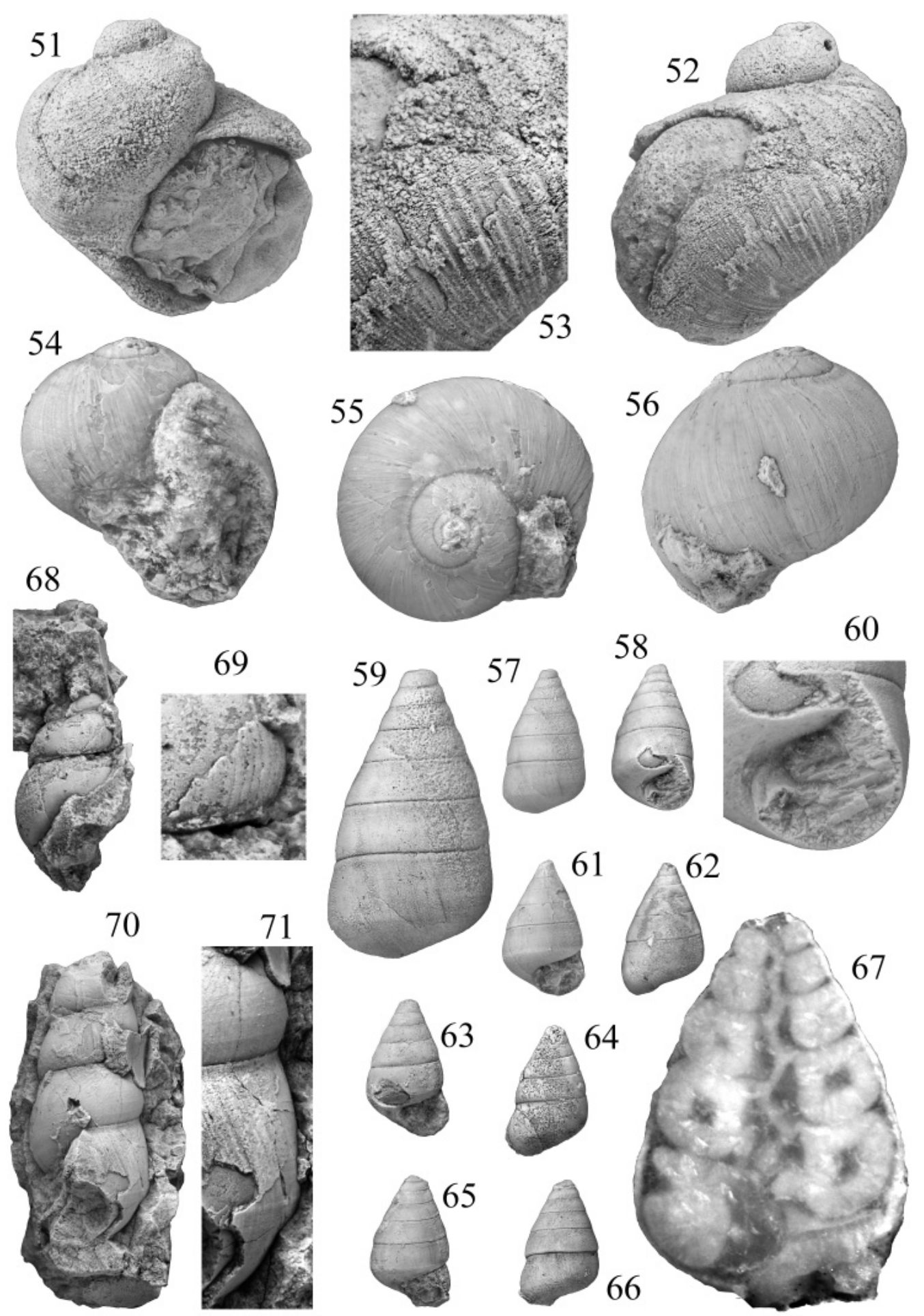

60
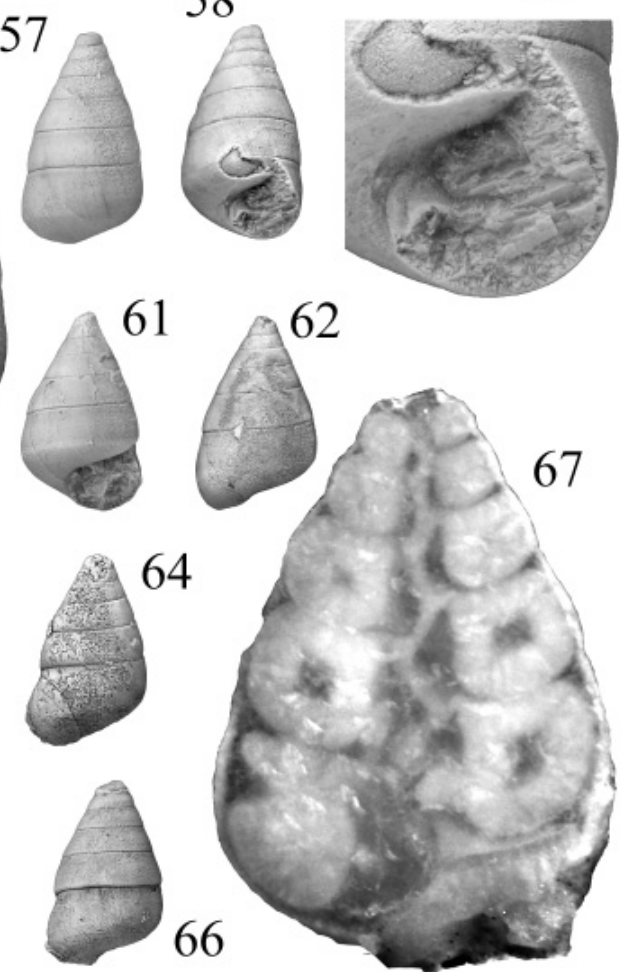
Occurrence - Within Sinemurian to lowermost Pliensbachian (Lower Jurassic) part of the Hierlatz Limestone Formation in Hierlatz Alpe, Hallstatt, Austria.

Hierlatzella arcana n. sp.

(Figs 57-67)

Type specimens - Holotype: GBA 2019/009/0033, paratypes (GBA 2019/009/ 0034-38).

Type locality - Hierlatz Alpe (Hallstatt, Austria).

Type strata - Lower Jurassic Hierlatz Limestone from the Semicostatum Zone (Lower Sinemurian) to Jamesoni Zone (Lower Pliensbachian) interval.

Derivation of name - Arcanus $($ Latin $)=$ mysterious.

Diagnosis - Same as for the genus.

Material - Eleven specimens (GBA 2019/009/0033-43), all of them without the protoconch and the earliest teleoconch whorls.

Measurements - Holotype (GBA 2019/009/0033), D = $3.8 \mathrm{~mm}$, paratype (GBA 2019/009/0034), D =3.8 mm, paratype (GBA 2019/009/0035), D = 3.9 mm, paratype (GBA 2019/009/0036), D = $3.7 \mathrm{~mm}$, paratype (GBA 2019/009/0037), $\mathrm{D}=3.8 \mathrm{~mm}$, paratype (GBA 2019/009/0038), $\mathrm{D}=4.1 \mathrm{~mm}$.

Description - Small, pupiform, thin-walled shells of low turriculate spire. Teleoconch whorls are initially low and flat with flush suture then slightly convex whorls and somewhat more impressed suture develop. Last whorl extends downward. Base is subglobose with convex wall; its transition to the last whorl is rounded-angular. No specimen has been found with undamaged peristome and earliest whorls. The aperture has depressed ovate outline, formed by a very short but complex columellar-umbilical lip, which is poorly preserved, thin outer lip and the parietal shell wall with probable discontinuity of the peristome. The shell interior contains a relatively thick columella with a spirally built, narrow umbilicus inside. No ornament has been found; the growth lines are very thin and slightly prosocline on the whorls and somewhat more on the base.

Figs 51-71. Species of Neritimorpha and Caenogastropoda. - Figs 51-53. Colubrellopsis? sp. (GBA 2019/009/0031). - 51-52. Apertural and dorsal views, $\times 3$. - 53. Details of the ornament, $\times 5$. Figs 54-56. Neridomus? sp. (GBA 2019/009/0032), apertural, apical and dorsal views, $\times 3$. - Figs 57-67. Hierlatzella arcana n. gen. n. sp. - 57-60. Holotype (GBA 2019/009/0033). - 57. Dorsal view, $\times 3$. -58 . Slightly oblique apertural view, $\times 3$. -59 . Dorsal view, $\times 6$. -6 60. Slightly oblique apertural view, $\times 10$. - 61-62. Paratype (GBA 2019/009/0034), apertural and dorsal views, $\times 3$. 63-64. Paratype (GBA 2019/009/0035), apertural and dorsal views, $\times 3$. - 65-66. Paratype (GBA $2019 / 009 / 0036)$, apertural and dorsal views, $\times 3 .-67$. Nearly axial cross section of a paratype (GBA 2019/009/0037) to show the peculiar inner shell morphology, $\times 10$. - Figs 68-69. Coelostylina? sp1. (GBA 2019/009/0044). - 68. Lateral view, $\times 1$. - 69. Preserved shell part, $\times 4$. - Figs 70-71. Coelostylina? sp2. (GBA 2019/009/0045). - 70. Lateral view, $\times 1$. - 71. Ornament on the whorls, $\times 2.3$ 
Remarks - From Lower Jurassic strata, similarly sized and shaped gastropods have been published by Gemmellaro M. (1911) as Chemnitzia galatensis (Late Pliensbachian) and as Proconulus? cf. galatensis (Late? Sinemurian) by SzABó (1983, 2009). From these, Gemmellaro's species is different in having more acute spire and circular peristome but the second form is rather near in shape to Hierlatzella arcana n. sp. In the latter case, early shell riblets and spiral lineation on the base mean significant difference from the Hierlatz Alpe species. Their relation to Hierlatzella arcana n. sp. needs still further studies.

Occurrence - Within Sinemurian to lowermost Pliensbachian (Lower Jurassic) part of the Hierlatz Limestone Formation in Hierlatz Alpe, Hallstatt, Austria.

Genus ?Coelostylina Kittl, 1894

Type species - Melania conica Münster, 1841

Coelostylina? sp1.

(Figs 68-69)

Material - Single specimen (GBA 2019/009/0044) from a box, labelled as Chemnitzia sp.

Measurements $-\mathrm{D}=\sim 16 \mathrm{~mm}$, spiral angle: $\sim 35^{\circ}$.

Description - The remnants represent a thin shelled species, having moderately turriculate spire with about $35^{\circ}$ coiling angle in the latest growth phase. Three whorls are visible, which show a slightly ovate outline, so the apical angle must be considerably wider. The whorls are convex and an impressed suture separates them. A strongly rounded angulation is observable slightly above the suture on the earlier whorls, that is absent from the last whorl. The periphery nearly coincides with the midwhorl on the last whorl but it is nearer to the lower suture on the former whorls.

A little, eroded portion of the shell shows rather sparse, orthocline, and feebly opisthocyrt grooves on its surface and much wider, smooth, and flat bars in the interspaces under magnification. Regular corrugation of the margins of the bars may indicate dense, delicate spiral lineation in less damaged stage.

Occurrence - Within Sinemurian to lowermost Pliensbachian (Lower Jurassic) part of the Hierlatz Limestone Formation in Hierlatz Alpe, Hallstatt, Austria.

\section{Coelostylina? sp2.}

(Figs 70-71)

Material - Two fragmentary specimens (GBA 2019/009/0045-46) from boxes, labelled as Chemnitzia sp.

Measurements - The figured one (GBA 2019/009/0045), D = $16.6 \mathrm{~mm}$, spiral angle: $\sim 20^{\circ}$. 
Description - Last three whorls represent the figured specimen. They are remnants of a rather highly turriculate shell, consisting of moderately convex whorls with a narrow and shallow concavity along the adapical suture; top of the convexity lies nearer to the abapical suture. The suture itself is in a slightly impressed position and appears as a groove. In the latest growth phase, the convexity of the whorl surface enfeebles into almost flat. Concomitantly, the periphery shifts from the line of maximum convexity to the line in prolongation of the suture where a weak angulation also develops. The base is subconoidal with convex wall; no trace of an umbilicus is found. No intact part of the peristome is preserved; the shell cross-section in this area indicates an axially elongated aperture/peristome without siphonal outlet.

The last two whorls bear an ornament of obscure spiral threads; they are denser in a belt at the midwhorl and sparser abapically from the formerly mentioned ones. On the last whorl, a strong thread follows the angulation. Pieces of sharp cords are also visible in the periaxial area on the base. Growth lines are observable only on the last whorl; they are slightly prosocline and opisthocyrt between the suture and the periphery, and seem to be slightly prosocyrt and nearly orthocline on the base.

Occurrence - Within Sinemurian to lowermost Pliensbachian (Lower Jurassic) part of the Hierlatz Limestone Formation in Hierlatz Alpe, Hallstatt, Austria.

\section{CONCLUSION}

With this contribution, the overwhelming majority of the species are published that have been distinguishable at least with application of the open nomenclature on the genus level from the "Hierlatz Alpe" in the historical collections. Study of a few species has been still in course and some extreme poorly preserved specimens have remained that indicate about a dozen of additional species. A few new species are also in unprepared, recently collected material. Owing to recent advances in the gastropod systematics, some revisions have become also necessary.

In this part, four new genera are established on single species, which are apparently endemic around the locality that probably has meaning for palaeobiogeographical studies. Besides, finding the first neritoidean specimen calls our attention to the almost full absence of a major, mainly shallow water gastropod group.

Acknowledgements - I am grateful to Attila Vörös and Boglárka Erdei (Hungarian Natural History Museum, Budapest) for the helpful review of this paper. Furthermore, I am indebted to Irene Zorn, curator of the Geologische Bundesanstalt (Vienna, Austria) who provides firm museum background to the Hierlatz papers for lots of years. 


\section{REFERENCES}

BANDEL K. 2007: Description and classification of Late Triassic Neritimorpha (Gastropoda, Mollusca) from the St Cassian Formation, Italian Alps. - Bulletin of Geosciences 82: 215-274. https://doi.org/10.3140/bull.geosci.2007.03.215

BANDEL K. 2009: The slit bearing nacreous Archaeogastropoda of the Triassic tropical reefs in the St. Cassian Formation with evaluation of the taxonomic value of the selenizone. - Berliner paläobiologische Abhandlungen 10: 5-47.

BANDEL K. 2010: Relationships of the Triassic Eucycloidea Koken, 1897 (Mollusca, Gastropoda) to modern genera such as Pagodatrochus, Calliotropis and Euchelus, based on morphology of the early shell. - Bulletin of Geosciences 85: 435-486.

https://doi.org/10.3140/bull.geosci.1208

Bouchet P., Rocroi J.-P., Hausdorf B., Kaim A., Kano Y., Nützel A., Parkhaev P., Schrödl M. \& STRONG E. E. 2017: Revised classification, nomenclator and typification of gastropod and monoplacophoran families. - Malacologia 61: 1-526.

https://doi.org/10.4002/040.061.0201

FERRARI M. \& KAIM A. 2018: Onshore-offshore trend in the evolution of calliotropid gastropods expressed in shell morphology. - Journal of Systematic Palaeontology published online 3 January 2018. https://doi.org/10.1080/14772019.2017.1407371

Ferrari M., Kaim A. \& Damborenea S. E. 2014: The genera Calliotropis Seguenza and Ambercyclus n. gen. (Vetigastropoda, Eucyclidae) from the early Jurassic of Argentina. Journal of Paleontology 88: 1174-1188. https://doi.org/10.1666/13-147

Gemmellaro M. 1911: Sui fossili degli strati a Terebratula aspasia della Contrada Rocche Rosse presso Galai (prov. di Messina) (continuazione dell'opera omonima di G. G. Gemmellaro). Cefalopodi (fine), Gasteropodi. - Giornale di Scienze Naturali ed Economiche 28: 203-247, pls 8-10.

GRÜNDEL J. 2007: Gastropoden aus dem unteren Pliensbachium von Feuguerolles (Normandie, Frankreich). - Freiberger Forschungshefte C524: 1-34.

NÜTZEL A. \& ERwiN D. H. 2004: Late Triassic (Late Norian) gastropods from the Wallowa Terrane (Idaho, USA). - Paläontologische Zeitschrift 78(2): 361-416. https://doi.org/10.1007/BF03009231

Szabó J. 1983: Lower and Middle Jurassic Gastropods from the Bakony Mountains (Hungary). Part V. Supplement to Archaeogastropoda; Caenogastropoda. - Annales historico-naturales Musei nationalis hungarici 75: 27-46.

Szabó J. 1995: Eucyclidae (Eucycloidea, Gastropoda) as a Liassic palaeoecological index in the Transdanubian Central Range (Hungary). - Hantkeniana 1: 67-74, pl. 7.

SzABó J. 2009: Gastropods of the Early Jurassic Hierlatz Limestone Formation; part 1: a revision of the type collections from Austrian and Hungarian localities. - Fragmenta Palaeontologica Hungarica 26: 1-108.

SzABó J. 2017: Gastropods of the Lower Jurassic Hierlatz Limestone Formation, part 2. Some new archaic type slit-bearing components from the fauna of the Hierlatz Alpe (Hallstatt, Austria) and the Bakony Mts (Hungary). - Fragmenta Palaeontologica Hungarica 33: 3-30. https://doi.org/10.17111/FragmPalHung.2016.33.3

SzABó J. 2018: Gastropods of the Lower Jurassic Hierlatz Limestone Formation, part 3. New pleurotomarioideans from the fauna of Hierlatz Alpe (Hallstatt, Austria). - Fragmenta Palaeontologica Hungarica 34: 9-48. https://doi.org/10.17111/FragmPalHung.2017.34.9

Szabó J., Conti M. A., Monari S. \& Wendt J. in press: Gastropods from the neptunian sills of Rocca Busambra (North-Western Sicily, Italy); Patellogastropoda, Pleurotomarioidea, Scissurelloidea, Fissurelloidea and Eucycloidea. - Papers in Palaeontology 